\title{
Lactococci of Local Origin as Potential Starter Cultures for Traditional Montenegrin Cheese Production
}

\author{
Mirjana Bojanic Rasovic ${ }^{1}$, Sigrid Mayrhofer ${ }^{2 *}$, Aleksandra Martinovic ${ }^{3}$, \\ Katharina Dürr ${ }^{2}$ and Konrad J. Domig ${ }^{2}$ \\ ${ }^{1}$ University of Montenegro, Biotechnical Faculty, Mihaila Lalića 1, ME-20000 Podgorica, Montenegro \\ ${ }^{2}$ BOKU - University of Natural Resources and Life Sciences, Department of Food Science and Technology, \\ Muthgasse 18, AT-1190 Vienna, Austria \\ ${ }^{3}$ University of Donja Gorica, Faculty of Food Technology, Food Safety and Ecology, Donja Gorica, \\ ME-81000 Podgorica, Montenegro \\ Received: June 28, 2016 \\ Accepted: November 8, 2016
}

\begin{abstract}
Summary
The aim of this study is to characterise and examine the biochemical properties of 40 Lactococcus lactis strains isolated from indigenous Montenegrin dairy products in order to explore their potential to be used as starter cultures for producing typical Montenegrin cheese, such as 'bijeli sir', 'masni sir' and 'njeguški sir'. Their safety regarding the production of biogenic amines, the presence of antimicrobial resistance and the antibacterial activity against relevant pathogens and spoilage microorganisms has also been tested. Based on the characterisation, all strains belong to L. lactis ssp. lactis. Out of these 40 strains, 23 displayed rapid acidification ability and proteolysis. However, none of the strains exhibited the ability of lipid degradation. Most of the strains were not associated with any health risk investigated. Summing up, a large percentage $(27.5 \%)$ of the tested strains showed good properties. These strains should be further examined for their possible application as specific starter cultures in the production of indigenous cheese in Montenegro.
\end{abstract}

Key words: Lactococcus lactis ssp. lactis, traditional Montenegrin cheese, starter cultures, technological properties, safety assessment

\section{Introduction}

Traditional manufacture of cheese from raw milk is an important feature of the Montenegrin culture. These types of cheese have a versatile taste, aroma and consistency when compared to industrially produced ones. The manufacture is generally carried out from unpasteurised milk, without the addition of defined starter cultures and by non-standardised technologies. Primarily, the activity of lactic acid bacteria, normally present in the milk and the production environment during fermentation and ripening, determines texture, aroma and flavour of these dairy products (1). Thus, this unique microflora adds to the specificity of cheese produced in the particular locali- ty $(2-4)$. Defined starter cultures, however, work faster and more reliably than the natural fermentation microbiota. They contribute to more predictable products with a positive impact on product quality and consumer health (5). Since there is no commercial production of starter cultures for Montenegrin soft and hard cheese types, only universal cultures from international manufacturers can be used. But such cultures are tailored for the needs of other markets and would not lead to products with typical properties of traditional Montenegrin cheese such as 'bijeli sir', 'masni sir' and 'njeguški sir' (6).

Of all lactic acid bacteria, particularly Lactococcus lactis plays a decisive role in the cheese making process (7). 
Thus, carefully selected strains of this species are major components of starter cultures for dairy fermentation (8). Testing lactococci isolated from indigenous fermented milk products could lead to the development of starter cultures with the necessary properties for the production of traditional Montenegrin cheese that is well accepted by the local population. After proper investigation, these microorganisms may find their application as starter cultures in the Montenegrin dairy industry for the production of safe and consistent cheese with designated geographical origin that could be placed on the international market.

The first stage in carefully selecting starters is to establish the precise identity of an isolate at genus and species level (9). Possible duplicates can be excluded by an analysis at strain level (10). Next to the correct identification, technological performance and stress resistance have to be characterised when screening for effective starters (9). The most important role of $L$. lactis strains in cheese production is their ability to rapidly produce lactic acid, which promotes the coagulation and formation of curd. Another essential characteristic is the possession of a proteolytic enzyme system enhancing the development of cheese flavour. Additionally, some lactococci can produce other aromatic compounds such as diacetyl and acetoin through the metabolism of citrate or lipids (11). Next to these technical aspects, a number of metabolites such as lactic acid and bacteriocins exhibit antimicrobial properties, which contribute to the safety of cheese or suppress spoilage (12). Furthermore, strains selected as starters must be safe. In this respect, possible hazards to human health such as the release of toxic compounds (9) or their ability to disseminate resistance determinants (13) should be verified.

Bearing in mind the importance of local starter cultures for the production of traditional cheese, we examined the potential use of L. lactis strains isolated from indigenous Montenegrin dairy products as starter cultures considering the properties mentioned above.

\section{Materials and Methods}

\section{Bacterial strains and growth conditions}

Lactococci were isolated previously (as described below) during the analysis of the diversity of lactic acid bacteria in Montenegrin soft (e.g. 'bijeli sir', 'masni sir') and hard (e.g. 'njeguški sir') cheese as well as in spontaneously fermented milk.

The strains were maintained in glycerol at $-80{ }^{\circ} \mathrm{C}$ and resuscitated in M17 broth (Merck, Darmstadt, Germany) according to Terzaghi and Sandine (14) at $30{ }^{\circ} \mathrm{C}$ overnight. This procedure was repeated twice. The resulting culture broth was used as precursor for the following tests, unless otherwise stated. In total 40 Lactococcus strains (Fig. 1) were included in the present study.

\section{Isolation and identification at species and strain level}

In brief, dilutions of the dairy products were inoculated on de Man, Rogosa and Sharpe (MRS; Merck) agar (15), and M17 agar (Merck) according to Terzaghi and Sandine (14). Both media were anaerobically incubated at $30{ }^{\circ} \mathrm{C}$ for $2-5$ days. Representative colonies were identi- fied at species level (primers gadB21 and Gad7) (16) and characterised at strain level (random amplification of polymorphic DNA (RAPD) primers M13 and 1283) $(17,18)$ using polymerase chain reaction (PCR)-based methods. Species-specific PCR was performed as described by Nomura et al. (16). RAPD-PCR for typing the isolates at strain level was conducted using a PCR mix $(25 \mu \mathrm{L})$ containing $1 \mu \mathrm{L}$ of DNA, $2.5 \mu \mathrm{L}$ of $10 \times$ PCR buffer (Finnzymes, Vantaa, Finland), $0.5 \mu \mathrm{L}$ of deoxyribonucleotide triphosphates (dNTPs; $10 \mathrm{mM}), 0.5 \mu \mathrm{L}$ of DNA polymerase $(2 \mathrm{U} /$ $\mu \mathrm{L}$; Dynazyme, Finnzymes), $18.5 \mu \mathrm{L}$ of sterile distilled water and $2 \mu \mathrm{L}$ of one of the two RAPD primers $(10 \mathrm{pmol} /$ $\mu \mathrm{L})$. The following PCR program was used: $95{ }^{\circ} \mathrm{C}$ for 5 min, then 45 cycles at $95^{\circ} \mathrm{C}$ for $60 \mathrm{~s}, 36^{\circ} \mathrm{C}$ for $60 \mathrm{~s}, 72^{\circ} \mathrm{C}$ for $60 \mathrm{~s}$, ending with $72{ }^{\circ} \mathrm{C}$ for $8 \mathrm{~min}$. PCR products were analysed by electrophoresis on a $2 \%$ agarose gel. The obtained RAPD patterns were additionally processed and analysed using the BioNumerics software v. 6.6.4 (Applied Maths, Sint-Martens-Latem, Belgium). Subsequently, a phylogenetic tree was created using the unweighted pair group method with arithmetic mean (UPGMA) by combining and clustering the fingerprint types of both RAPD primers (Fig. 1).

\section{Phenotypic characterisation of strains and determination of their stress resistance}

\section{Production of $\mathrm{CO}_{2}$}

The production of $\mathrm{CO}_{2}$ from glucose was investigated using a modified method of Winn et al. (19). Briefly, broth cultures of lactococci $(50 \mu \mathrm{L})$ were inoculated into a test tube containing $10 \mathrm{~mL}$ of M17 broth containing $1 \%$ glucose (Torlak, Belgrade, Serbia) and a Durham's tube. After 24-48 h of incubation at $30^{\circ} \mathrm{C}$, the gas production was observed. If the gas accumulated in the Durham's tube to more than one third of its capacity, the test was considered positive.

\section{Bacterial growth on M17 agar at different temperatures}

The M17 agar was inoculated with the L. lactis strains and incubated for $72 \mathrm{~h}$ at 4,10 and $45^{\circ} \mathrm{C}$. Afterwards, the agar was examined for bacterial growth by looking for the presence of colonies.

\section{Bacterial growth in $\mathrm{M} 17$ broth with $6.5 \% \mathrm{NaCl}$ or at $\mathrm{pH}=9.6$}

Bacterial growth was monitored over 5 days by measuring the absorbance using the Bioscreen C system (Labsystems, Helsinki, Finland), which includes an incubator, shaking functions and a photometer. Firstly, $300 \mu \mathrm{L}$ of M17 broth supplemented with $6.5 \% \mathrm{NaCl}$ (Roth, Karlsruhe, Germany) or with $\mathrm{pH}$ value adjusted to 9.6 were transferred to each well of two honeycomb plates (respectively 10×10 wells; Labsystems). Afterwards, a volume of $15 \mu \mathrm{L}$ of the broth culture of lactococci was pipetted into each well and the plates were incubated at $30{ }^{\circ} \mathrm{C}$ in the Bioscreen C system. The absorbance of the cell suspensions was measured automatically at $600 \mathrm{~nm}$ in regular intervals of $30 \mathrm{~min}$. Before each measurement, the culture wells were automatically shaken for $10 \mathrm{~s}$ at normal speed. The experiments were carried out in duplicate. Average values of the duplicate absorbance measurements were calculated and used to generate growth curves for each studied strain. 


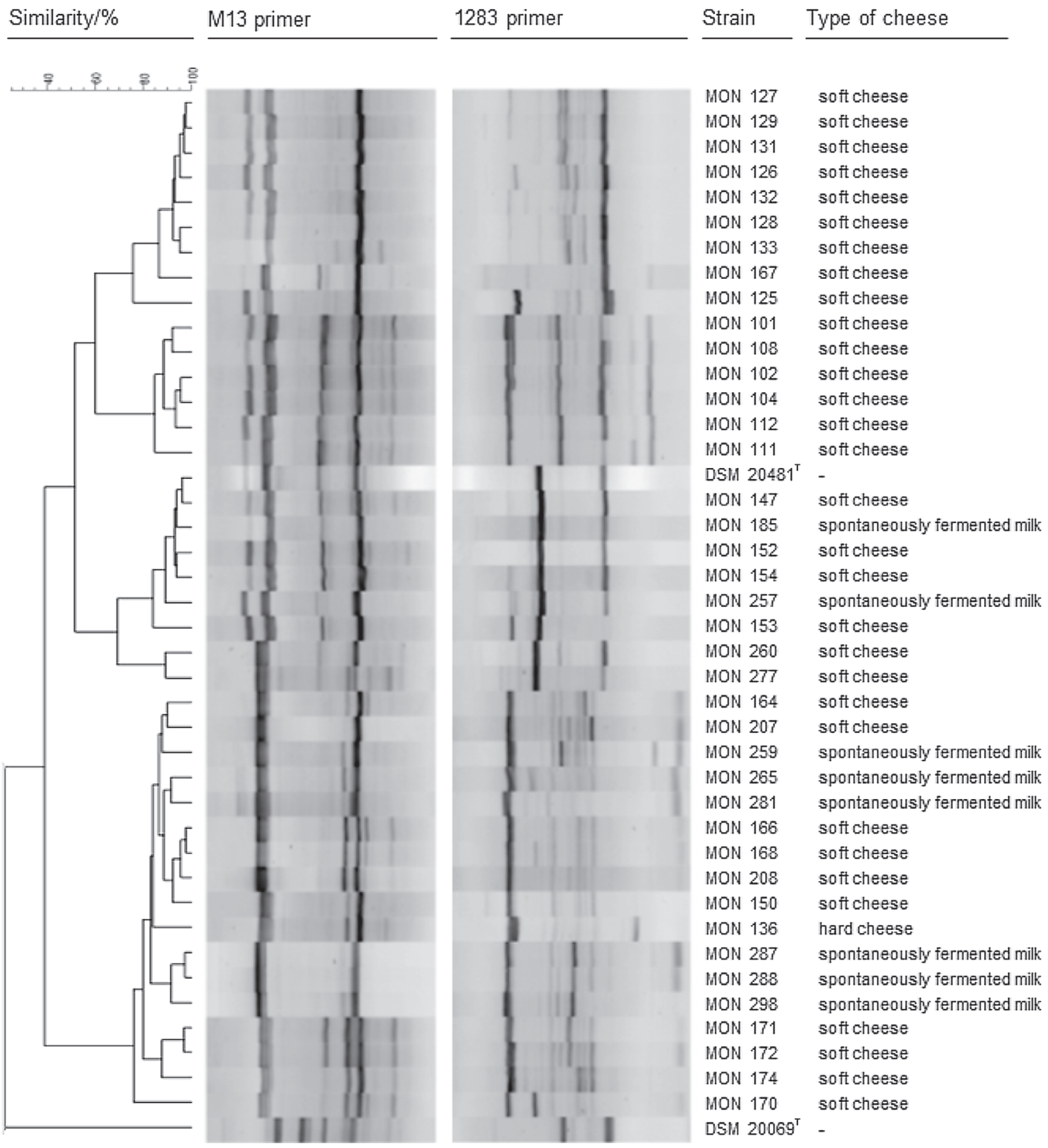

Fig. 1. Composite dataset of RAPD patterns obtained for 40 Lactococcus lactis test strains and two type strains, demonstrating genetic variability. MON=tested strains; DSM=Deutsche Sammlung von Mikroorganismen (German Collection of Microorganisms): DSM $20481^{\mathrm{T}}=$ Lactococcus lactis ssp. lactis, DSM 20069 ${ }^{\mathrm{T}}=$ Lactococcus lactis ssp. cremoris. Pearson's correlation: optimisation: $1 \%$, curve smoothing: $0 \%$, M13 active zone: $20-90 \% ; 1283$ active zone: $30-100 \%$

Production of exopolysaccharides

The production of exopolysaccharides (EPS) was checked by looking for mucous L. lactis colonies grown on M17 agar. Additionally, such colonies were extended with an inoculation loop to detect the production of long filaments. If there were no slimy colonies or the formation of long filaments was missing, it was concluded that the strain did not produce EPS.

\section{Citrate utilisation}

Lactococci were streaked on Simmons citrate agar (Oxoid, Hampshire, UK), containing citrate and bromothymol blue as $\mathrm{pH}$ indicator. An increase in $\mathrm{pH}$ due to the reduction of citrate and the production of alkaline by-products resulted in a colour change from green to blue.

\section{Acetoin production}

Methyl red-Voges Proskauer (MR-VP) broth (Oxoid) was inoculated with the microorganisms and incubated at $30{ }^{\circ} \mathrm{C}$ for $72 \mathrm{~h}$. After incubation, $2.5 \mathrm{~mL}$ of the incubated broth were taken and $0.6 \mathrm{~mL}$ of $\mathrm{VP}$ reagent A (5\% $\alpha$-naphthol in absolute ethanol; Roth) and $0.2 \mathrm{~mL}$ of VP reagent $\mathrm{B}\left(40 \% \mathrm{KOH}\right.$ in distilled $\mathrm{H}_{2} \mathrm{O}$; Merck) were added, mixed thoroughly and left at room temperature for 10-30 $\mathrm{min}$. The production of acetoin was indicated by a colour change of the medium to red. 


\section{Technological performance of strains}

Acidification and post-acidification ability in milk

The acidification and post-acidification ability of each strain was tested by inoculating $50 \mu \mathrm{L}$ of broth culture in $50 \mathrm{~mL}$ of ultra-high temperature (UHT) processed skimmed cow's milk with $2.8 \%$ fat (Imlek, Belgrade, Serbia). Incubation was done at $30{ }^{\circ} \mathrm{C}$ for $48 \mathrm{~h}$ and the resulting $\mathrm{pH}$ values were measured after 2, 4, 6, 8, 12 and $24 \mathrm{~h}(6)$. The ability of post-acidification was investigated by measuring the $\mathrm{pH}$ of the inoculated skimmed milk after $48 \mathrm{~h}$ of incubation.

\section{Activity of $\beta$-galactosidase}

The activity of $\beta$-galactosidase was measured on ortho-nitrophenyl- $\beta$-D-galactopyranoside (ONPG) disks according to the manufacturer's instructions (20) with minor modifications. In brief, L. lactis colonies grown on M17 agar were emulsified in $0.1 \mathrm{~mL}$ of $0.85 \% \mathrm{NaCl}$ solution containing one ONPG disc. The appearance of yellow colour after incubation at $30{ }^{\circ} \mathrm{C}$ for $24 \mathrm{~h}$ indicated $\beta$-galactosidase activity.

\section{Proteolytic activity}

Lines of L. lactis strains were streaked on the surface of $3 \%$ nutritive agar (Torlak) supplemented with $3 \%$ sterile skimmed milk (with $1.5 \%$ fat; Imlek). The inoculated medium was incubated at $30{ }^{\circ} \mathrm{C}$ for $24 \mathrm{~h}$. The presence of clear transparent zones around the colonies indicated proteolytic activity.

\section{Lipolytic activity}

Tributyrin agar (Torlak) was inoculated with $100 \mu \mathrm{L}$ of decimal dilutions of tested strains by pour plate method. Transparent zones around the colonies after an incubation for $72 \mathrm{~h}$ at $30^{\circ} \mathrm{C}$ implied lipolytic activity.

\section{Properties of strains contributing to the safety of cheese}

Antimicrobial activity of lactococci against selected microorganisms

The antimicrobial activity of lactococci against relevant pathogens and spoilage microorganisms was tested by an agar streak and spot method according to Domig et al. (10) with minor modifications. Strains or isolates of Staphylococcus aureus, Listeria spp., Escherichia spp., Enterobacter spp., Serratia spp. and Pseudomonas spp., originating from the German Collection of Microorganisms and Cell Cultures (DSMZ, Braunschweig, Germany) or isolated from the same dairy products as the Lactococcus strains, were used as indicator microorganisms. L. lactis colonies incubated for $24 \mathrm{~h}$ in brain heart infusion (BHI) agar (Oxoid) were transferred to $5 \mathrm{~mL}$ of $0.85 \% \mathrm{NaCl}$ solution. Subsequently, the inoculum was adjusted to McFarland standard no. 1 and streaked in two parallel lines about 20 $\mathrm{mm}$ apart on the centre of a BHI agar plate. After incubating the plates for $24 \mathrm{~h}$ at $32{ }^{\circ} \mathrm{C}$, inocula of indicator microorganisms were prepared in the same way as those of the lactococci. Of these, $5 \mu \mathrm{L}$ were dropped between the two pre-incubated Lactococcus streaks and separately on the margin of the BHI agar plates as growth control. The plates were again incubated at $32{ }^{\circ} \mathrm{C}$ for $24 \mathrm{~h}$ and evaluated afterwards. The absence of growth of the indicator mi- croorganisms between the two Lactococcus streaks and growth at the margin of the agar plates indicates the presence of antimicrobial substances.

Subsequently, the agar well diffusion assay was used to screen for bacteriocin-producing isolates among lactococci which inhibited the growth of Staphylococcus aureus in the previous test. S. aureus DSM 1104 and S. aureus DSM 20231 from the DSMZ collection as well as one isolate from cheese (SA 17) were applied as indicator bacteria. These indicator microorganisms were inoculated in 15 $\mathrm{mL}$ of BHI broth, whereas MRS broth was utilised for the test strains. All were incubated overnight at $32{ }^{\circ} \mathrm{C}$. The analysis was conducted according to Yang et al. (21) with minor modifications. Hence, $1 \mathrm{~mL}$ of each indicator bacterium was transferred to $15 \mathrm{~mL}$ of liquid $\mathrm{BHI}$ agar maintained at $50{ }^{\circ} \mathrm{C}$ and immediately poured into a Petri dish. After solidification, four wells (5 $\mathrm{mm}$ in diameter) were cut and $35 \mu \mathrm{L}$ of cell-free supernatant (CFS) from a Lactococcus strain were added to each well.

CFSs were prepared as follows: $13 \mathrm{~mL}$ of the incubated broth were centrifuged at $14000 \times g$ for 5 min (Eppendorf, Hamburg, Germany). The supernatant was filtered through a sterile $0.22-\mu \mathrm{m}$ syringe filter and $35 \mu \mathrm{L}$ of this sterile CFS were added to the first well. The remaining CFS was adjusted to $\mathrm{pH}=6.5$ to rule out $\mathrm{pH}$ effects due to the presence of organic acids. This neutralised CFS was filtered and $35 \mu \mathrm{L}$ were added to the second well. Subsequently, the neutralised CFS was treated with catalase (1 $\mathrm{mg} / \mathrm{mL}$; Sigma-Aldrich, St. Louis, MO, USA) at $25^{\circ} \mathrm{C}$ for $30 \mathrm{~min}$ to eliminate the possible inhibitory activity of $\mathrm{H}_{2} \mathrm{O}_{2}$, filtered and transferred to the third well. The fourth well was filled with $35 \mu \mathrm{L}$ of $1 \mathrm{mg} / \mathrm{mL}$ of nisin (Sigma-Aldrich), which was used as positive control. After incubation at $37^{\circ} \mathrm{C}$ for $24 \mathrm{~h}$ the growth inhibition was determined.

\section{Screening for decarboxylase genes}

Bacterial DNA was obtained using the Peqgold DNA isolation kit (Peqlab, Erlangen, Germany) (22) according to the manufacturer's protocol. The primer pairs JV17HC/ JV16HC (23), P1/P0303 (24,25, respectively) and ODCf/ ODCr (26) were used to allow the detection of genes involved in the production of histamine (histidine decarboxylase, HDC), tyramine (tyrosine decarboxylase, TDC) and putrescine (ornithine decarboxylase, ODC). PCR reactions were performed as described above with minor modifications: $0.25 \mu \mathrm{L}$ of DNA polymerase $(2 \mathrm{U} / \mu \mathrm{L}), 1 \mu \mathrm{L}$ of each primer $(10 \mathrm{pmol} / \mu \mathrm{L})$ and $18.75 \mu \mathrm{L}$ of sterile distilled water were used instead of the previously mentioned amounts. The following PCR program was used: $95^{\circ} \mathrm{C}$ for $5 \mathrm{~min}$, then 30 (HDC), 35 (TDC) or 40 (ODC) cycles at $95{ }^{\circ} \mathrm{C}$ for $60 \mathrm{~s}, 48{ }^{\circ} \mathrm{C}$ (HDC) or $55^{\circ} \mathrm{C}$ (TDC and ODC) for $60 \mathrm{~s}, 72{ }^{\circ} \mathrm{C}$ for $60 \mathrm{~s}$ ending with $72{ }^{\circ} \mathrm{C}$ for $8 \mathrm{~min}$. PCR products were analysed by electrophoresis on a $2 \%$ agarose gel.

PCR products of interest were purified with the PCRExtract Mini Kit (5 Prime GmbH, Hilden, Germany) and subjected to commercial sequencing (Eurofins MWG Operon, Ebersberg, Germany). Sequence compilation and comparison were performed using the nucleotide basic local alignment search tool (BLAST) at the National Center for Biotechnology Information (NCBI) (27). 
Antimicrobial susceptibility testing

The antimicrobial susceptibility of all strains against ampicillin (AMP), vancomycin (VAN), gentamicin (GEN), kanamycin (KAN), streptomycin (STR), erythromycin (ERY), clindamycin (CLI), tetracycline (TET) and chloramphenicol (CHL) were determined by broth microdilution according to the ISO 10932/IDF 233:2010 method (28) with minor modifications. All antibiotics originated from Sigma-Aldrich and were dissolved in water for preparing stock solutions, except for erythromycin and chloramphenicol. To dissolve these two antibiotics, $95 \%$ ethanol was used in volumes as low as possible. Subsequently, stock solutions were diluted in water to obtain solutions with preliminary concentrations in the ranges of (in $\mu \mathrm{g} / \mathrm{mL}$ ): 0.03 32 (ERY), 0.06-64 (CLI), 0.25-256 (AMP, VAN and CHL), 0.5-512 (GEN and TET), 1-1024 (STR) and 2-2048 (KAN). A volume of $50 \mu \mathrm{L}$ of each solution was dispensed in the wells of the microtiter plates.

Bacterial inocula were prepared by suspending colonies from 24-hour incubated M17 agar in $5 \mathrm{~mL}$ of $0.85 \%$ $\mathrm{NaCl}$ solution. Subsequently, inocula were adjusted to McFarland standard no. 1 and diluted in a ratio of 1:500 in double strength Iso-Sensitest broth (Oxoid) for inoculation of the microtiter plates by adding $50 \mu \mathrm{L}$ of diluted inoculum to each well. This resulted in the final antibiotic concentration ranges of (in $\mu \mathrm{g} / \mathrm{mL}$ ): 0.01-16 (ERY), 0.03 32 (CLI), 0.12-128 (AMP, VAN and CHL), 0.25-256 (GEN and TET), 0.5-512 (STR) and 1-1024 (KAN). After incubating the plates under anaerobic conditions at $32{ }^{\circ} \mathrm{C}$ for $48 \mathrm{~h}$, the minimum inhibitory concentration (MIC) was read as the lowest concentration of an antimicrobial agent at which visible growth was inhibited. The accuracy of susceptibility testing was monitored by parallel use of the quality control strain Lactococcus lactis ATCC 19435.

\section{Results and Discussion}

\section{Characterisation of strains}

L. lactis ssp. cremoris and L. lactis ssp. lactis as well as its diacetyl-forming biovariety L. lactis ssp. lactis biovar. diacetylactis are the most common L. lactis subspecies found in dairy environments $(8,29)$. L. lactis ssp. lactis is usually differentiated from L. lactis ssp. cremoris by its tolerance to higher temperatures and salt concentrations (8). Only the latter species can produce EPS, which is useful for the modification of texture and rheological properties in dairy products (29). All tested L. lactis strains did not create EPS and two thirds of the strains $(67.5 \%)$ were able to grow in the presence of $6.5 \% \mathrm{NaCl}$. Moreover, L. lactis ssp. lactis can be distinguished from its diacetyl-forming biovariety on the basis of citrate fermentation, which leads to the production of aromatic compounds such as diacetyl and acetoin. Because none of the strains could degrade citrate or produce acetoin, all strains were assigned to L. lactis ssp. lactis (Table 1).

Furthermore, the inability to produce $\mathrm{CO}_{2}$ from glucose and to grow in the presence of $6.5 \% \mathrm{NaCl}$, at $45^{\circ} \mathrm{C}$ or at $\mathrm{pH}=9.6$ was considered to be specific for lactococci (30). These criteria are often used to differentiate lactococci from enterococci. Except for the lack of $\mathrm{CO}_{2}$ production, which is typical for homofermentative lactococci and a
Table 1. Phenotypical and biochemical properties of 40 tested Lactococcus lactis strains

\begin{tabular}{|c|c|c|c|c|c|c|c|c|c|}
\hline \multirow{3}{*}{$\begin{array}{l}\text { Tested } \\
\text { strain }\end{array}$} & \multirow{3}{*}{ 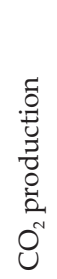 } & \multirow{3}{*}{ 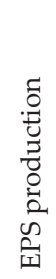 } & \multirow{3}{*}{ 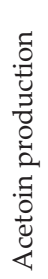 } & \multirow{3}{*}{ 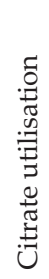 } & \multicolumn{5}{|c|}{ Growth conditions } \\
\hline & & & & & \multicolumn{3}{|c|}{$t /{ }^{\circ} \mathrm{C}$} & \multirow{2}{*}{ 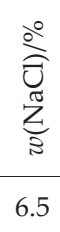 } & \multirow[b]{2}{*}{$\mathrm{pH}=9.6$} \\
\hline & & & & & 4 & 10 & 45 & & \\
\hline MON101 & - & - & - & - & - & + & + & + & + \\
\hline MON102 & - & - & - & - & - & + & - & + & + \\
\hline MON104 & - & - & - & - & - & + & + & + & + \\
\hline MON108 & - & - & - & - & - & + & - & + & + \\
\hline MON111 & - & - & - & - & - & + & + & + & + \\
\hline MON112 & - & - & - & - & - & + & + & + & + \\
\hline MON125 & - & - & - & - & - & + & - & - & - \\
\hline MON126 & - & - & - & - & - & + & - & + & - \\
\hline MON127 & - & - & - & - & - & + & - & - & - \\
\hline MON128 & - & - & - & - & - & + & - & - & - \\
\hline MON129 & - & - & - & - & - & + & - & - & + \\
\hline MON131 & - & - & - & - & - & + & - & - & - \\
\hline MON132 & - & - & - & - & - & + & - & + & - \\
\hline MON133 & - & - & - & - & - & + & - & - & - \\
\hline MON136 & - & - & - & - & - & + & - & - & - \\
\hline MON147 & - & - & - & - & - & + & + & + & - \\
\hline MON150 & - & - & - & - & - & + & - & + & - \\
\hline MON152 & - & - & - & - & - & + & - & + & - \\
\hline MON153 & - & - & - & - & - & + & - & + & - \\
\hline MON154 & - & - & - & - & - & + & - & - & - \\
\hline MON164 & - & - & - & - & - & + & - & + & + \\
\hline MON166 & - & - & - & - & - & + & - & + & - \\
\hline MON167 & - & - & - & - & - & + & - & + & + \\
\hline MON168 & - & - & - & - & - & + & - & + & - \\
\hline MON170 & - & - & - & - & - & + & - & + & - \\
\hline MON171 & - & - & - & - & - & + & - & + & - \\
\hline MON172 & - & - & - & - & - & + & - & - & - \\
\hline MON174 & - & - & - & - & - & + & - & - & - \\
\hline MON185 & - & - & - & - & - & + & - & + & - \\
\hline MON207 & - & - & - & - & - & + & - & - & - \\
\hline MON208 & - & - & - & - & - & + & - & + & - \\
\hline MON257 & - & - & - & - & - & + & - & + & - \\
\hline MON259 & - & - & - & - & - & + & - & - & - \\
\hline MON260 & - & - & - & - & - & + & - & + & - \\
\hline MON265 & - & - & - & - & - & + & - & + & - \\
\hline MON277 & - & - & - & - & - & + & - & + & - \\
\hline MON281 & - & - & - & - & - & + & - & + & - \\
\hline MON287 & - & - & - & - & - & + & - & + & - \\
\hline MON288 & - & - & - & - & - & + & - & + & - \\
\hline MON298 & - & - & - & - & - & + & - & - & - \\
\hline
\end{tabular}

EPS=exopolysaccharides 
desired trait for the production of full-fat cheese without holes (31), the other criteria could not be totally verified within this study (Table 1). Thus, $67.5 \%$ of the strains grew in the presence of $6.5 \% \mathrm{NaCl}, 12.5 \%$ grew at $45^{\circ} \mathrm{C}$ and $22.5 \%$ at $\mathrm{pH}=9.6$. Similar results were obtained by Facklam and Elliott (32), who recommend a careful interpretation of weak test results, and Corroler et al. (33), who assume that not enough strains have been characterised to consider an inability to grow at $\mathrm{pH}=9.6$ or in the presence of $6.5 \% \mathrm{NaCl}$ to be specific for lactococci. Additionally, many industrially important traits may be unstable as they are plasmid mediated in L. lactis (34). However, growth of lactococci in the presence of $6.5 \% \mathrm{NaCl}$ and at higher or lower temperatures would not be surprising, because these microorganisms survive in hostile conditions and are commonly exposed to many stresses (33). Being able to grow at low temperatures, lactococci can continue to keep the product from spoiling and inhibit the growth of pathogenic microorganisms $(35,36)$. None of the strains was able to grow at $4{ }^{\circ} \mathrm{C}$, but all grew at 10 ${ }^{\circ} \mathrm{C}$ (Table 1). Furthermore, growth at $45^{\circ} \mathrm{C}$, shown by 12.5 $\%$ of the tested strains, could indicate their adaptation to local climatic conditions (37). For the manufacturing of traditional products, which are usually made with high $\mathrm{NaCl}$ concentrations (38-40), growth in the presence of high $\mathrm{NaCl}$ concentrations would also be a good criterion.

\section{Technological suitability of strains as starter cultures}

Acidification and rapid production of lactic acid are the most important criteria in the selection of starter cultures for cheese production (3,41-43). Strains with good acidification ability decrease the $\mathrm{pH}$ of milk from its normal value of 6.6 to a $\mathrm{pH}=5.3$ within $6 \mathrm{~h}$ or to a $\mathrm{pH}<4.8$ or 4.65 within $24 \mathrm{~h}$ of incubation at the optimal temperature (44). Taking this essential characteristic into account, the tested strains were classified into three groups based on their acidification ability in UHT milk with $2.8 \%$ fat. The first group consisted of $23(57.5 \%)$ fast milk-coagulating strains, which lowered the $\mathrm{pH}$ of milk below 4.65 after 24 $\mathrm{h}$ of incubation. This group represents a collection of potential starter microorganisms. The second group with slower acidification ability ( $\mathrm{pH}=4.65)$ comprised one milk-coagulating strain (2.5\%). Sixteen strains (40\%) that were characterised by a slow acidification ability $(\mathrm{pH}>4.65)$ comprised the third group. With these strains no coagulation of milk was observed within $24 \mathrm{~h}$; moreover, $37.5 \%$ of them were not able to coagulate the milk even within $48 \mathrm{~h}$ of incubation (Table 2).

The storage life of fermented products is largely influenced by the post-acidification ability of the used starters (30). Hence, attention is also paid to post-acidification properties when selecting starter cultures. Within this study the post-acidification was calculated by the difference of the $\mathrm{pH}$ value after 24 and $48 \mathrm{~h}$ of incubation. Strains with a difference between 0 to $0.49 \mathrm{pH}$ units were considered as strains with a low or absent post-acidification ability (44). This is a good feature from the perspective of their possible use as starter cultures because the consistency and sensory properties of the product will be maintained (45). All strains in the first and second group had weak post-acidification ability (Table 2).

Lactose is the main carbohydrate metabolised by two different pathways in lactococci to provide energy. The common pathway employs a lactose-specific phosphoenolpyruvate (PEP)-dependent phosphotransferase system (PTS). The resulting lactose phosphate is hydrolysed by phospho- $\beta$-D-galactosidase to glucose and galactose-6-phosphate, which are simultaneously metabolised to pyruvate. Pyruvate is mainly converted into lactic acid (46). The amount of lactic acid is sufficient to overcome the buffering system of milk during an extended incubation (48-72 h) resulting in an acidic environment (41).

The second pathway of lactose utilisation employs a carbohydrate-specific permease and $\beta$-galactosidase, importing and cleaving lactose to glucose and galactose, which are further metabolised (46). ONPG is a compound structurally similar to lactose except that glucose has been replaced by ortho-nitrophenyl. Strains possessing both enzymes are able to hydrolyse ONPG into galactose and ortho-nitrophenol. Ortho-nitrophenol is a chromophore that is colourless when bound to D-galactopyranoside, but yellow in its free form (20). Eighteen strains (78.3\%) of the 23 potential starter cultures showed the ability to decompose ONPG (Table 2). These lactococci are capable of carrying out a rapid acidification in milk (47-49).

All lactococci of the first and second group and $25 \%$ of the third group could degrade casein (Table 2). Proteolysis is crucial in the process of cheese ripening and undoubtedly the most important biochemical process for the formation of taste and smell of cheese. Thus, the ability to break down casein plays a key role in the selection of cheese starters. The degradation of casein by proteinases and peptidases from starter cultures leads to small peptides and free amino acids. These are the main precursors of volatile compounds which are required for the development of the specific cheese flavour. Next to this, proteolysis is important for the desired texture $(50,51)$. Lactococci also require proteins, peptides and amino acids for their own growth. Since the content of free amino acids in milk is not sufficient, they depend on their own proteolytic system utilising casein. However, the occurrence of non-proteolytic lactococci, which do not grow after depletion of all free amino acids, was also reported (52).

Next to proteolysis, lipolysis of milk fat by lactic acid bacteria influences the cheese flavour development (53). Generally, lipolysis refers to the hydrolysis of triglycerides by the enzyme lipase and results in the formation of free fatty acids, which may be precursors of aromatic components such as methyl ketones, secondary alcohols, esters and lactones $(54,55)$. Compared to other bacterial groups, lactic acid bacteria are considered as weakly lipolytic (56). This corresponds to our findings, as all tested strains did not display transparent zones around the colonies on tributyrin agar after incubation (Table 2). Also a $L$. lactis strain investigated by Katz et al. (53) did not show any lipase activity, whereas Meyers et al. (57) observed a weak one in some lactococci.

\section{Cheese safety issues}

The antimicrobial activity of LAB is due to their production of organic acids, carbon dioxide, hydrogen peroxide, diacetyl, fatty acids, bacteriocins, bacteriocin-like 
Table 2. Technological properties of 40 tested Lactococcus lactis strains

\begin{tabular}{|c|c|c|c|c|c|c|c|c|c|c|}
\hline \multirow{3}{*}{$\begin{array}{l}\text { Tested } \\
\text { strain }\end{array}$} & \multirow{3}{*}{ Group } & \multicolumn{6}{|c|}{$t / h$} & \multirow{3}{*}{$\begin{array}{c}\beta \text {-galactosidase } \\
\text { activity }\end{array}$} & \multirow{3}{*}{ Proteolysis } & \multirow{3}{*}{ Lipolysi } \\
\hline & & 2 & 4 & 6 & 8 & 24 & 48 & & & \\
\hline & & \multicolumn{6}{|c|}{$\mathrm{pH}$ (milk at $\left.30^{\circ} \mathrm{C}\right)$} & & & \\
\hline MON101 & 1 & 6.19 & 5.77 & 5.20 & $4.56^{*}$ & 4.08 & 4.03 & + & + & - \\
\hline MON102 & 1 & 6.34 & 6.20 & 6.03 & 5.69 & $4.46^{*}$ & 4.21 & + & + & - \\
\hline MON104 & 1 & 6.28 & 5.94 & 5.31 & $4.58^{*}$ & 4.10 & 4.06 & + & + & - \\
\hline MON108 & 1 & 6.24 & 5.78 & 5.18 & $4.51^{*}$ & 4.09 & 4.07 & + & + & - \\
\hline MON111 & 1 & 6.32 & 6.05 & 5.58 & 4.88 & $4.10^{*}$ & 4.04 & + & + & - \\
\hline MON112 & 1 & 6.25 & 6.10 & 5.69 & 5.07 & $4.11^{*}$ & 4.03 & + & + & - \\
\hline MON125 & 3 & 6.39 & 6.31 & 6.26 & 6.18 & 5.28 & $4.17^{*}$ & - & - & - \\
\hline MON126 & 1 & 6.30 & 5.80 & 5.16 & $4.62^{*}$ & 4.17 & 4.11 & + & + & - \\
\hline MON127 & 3 & 6.32 & 6.04 & 5.69 & 5.43 & $4.69^{*}$ & 4.31 & - & + & - \\
\hline MON128 & 3 & 6.33 & 6.31 & 6.21 & 6.23 & 6.05 & 5.87 & - & - & - \\
\hline MON129 & 1 & 6.38 & 6.24 & 6.11 & 6.04 & $4.29^{*}$ & 4.12 & + & + & - \\
\hline MON131 & 3 & 6.34 & 6.26 & 6.18 & 6.13 & 6.04 & 5.85 & - & - & - \\
\hline MON132 & 1 & 6.25 & 5.97 & 5.61 & 5.37 & $4.62^{*}$ & 4.27 & - & + & - \\
\hline MON133 & 3 & 6.34 & 6.35 & 6.33 & 6.35 & 5.05 & $4.24^{*}$ & - & - & - \\
\hline MON136 & 1 & 6.28 & 5.87 & 5.40 & 5.12 & $4.49^{*}$ & 4.31 & + & + & - \\
\hline MON147 & 1 & 6.29 & 6.05 & 5.49 & 5.08 & $4.40^{*}$ & 4.16 & - & + & - \\
\hline MON150 & 3 & 6.30 & 6.09 & 5.96 & 6.67 & 5.12 & $4.76^{*}$ & - & + & - \\
\hline MON152 & 1 & 6.28 & 5.98 & 5.44 & 5.08 & $4.40^{*}$ & 4.18 & - & + & - \\
\hline MON153 & 1 & 6.33 & 6.09 & 5.57 & 5.26 & $4.56^{*}$ & 4.26 & - & + & - \\
\hline MON154 & 1 & 6.29 & 5.75 & 5.40 & 5.20 & $4.55^{*}$ & 4.29 & - & + & - \\
\hline MON164 & 1 & 6.18 & 5.45 & $4.60^{*}$ & 4.31 & 4.05 & 4.04 & + & + & - \\
\hline MON166 & 1 & 6.32 & 5.96 & 5.50 & 5.22 & $4.42^{*}$ & 4.19 & + & + & - \\
\hline MON167 & 1 & 6.33 & 5.90 & 5.43 & 5.15 & $4.55^{*}$ & 4.28 & + & + & - \\
\hline MON168 & 3 & 6.31 & 6.21 & 6.15 & 6.10 & 5.70 & 5.29 & + & + & - \\
\hline MON170 & 1 & 5.96 & 5.39 & 5.11 & $4.90^{*}$ & 4.30 & 4.13 & + & + & - \\
\hline MON171 & 3 & 6.27 & 6.16 & 6.09 & 6.03 & 5.61 & $4.62^{*}$ & + & - & - \\
\hline MON172 & 3 & 6.25 & 6.12 & 6.09 & 6.00 & 5.60 & $4.42^{*}$ & + & - & - \\
\hline MON174 & 3 & 6.31 & 6.21 & 6.16 & 6.04 & 5.71 & 5.42 & + & - & - \\
\hline MON185 & 1 & 6.28 & 5.88 & 5.15 & $4.47^{*}$ & 4.10 & 4.07 & + & + & - \\
\hline MON207 & 3 & 6.29 & 6.20 & 6.11 & 6.06 & 5.72 & 5.44 & - & - & - \\
\hline MON208 & 1 & 6.26 & 5.85 & 5.40 & 5.18 & $4.47^{*}$ & 4.22 & + & + & - \\
\hline MON257 & 3 & 6.38 & 6.29 & 6.29 & 6.23 & 6.24 & 6.13 & - & - & - \\
\hline MON259 & 3 & 6.40 & 6.30 & 6.28 & 6.20 & 5.24 & $4.32^{*}$ & - & - & - \\
\hline MON260 & 3 & 6.29 & 6.10 & 5.97 & 5.75 & 5.08 & $4.68^{*}$ & + & + & - \\
\hline MON265 & 1 & 6.23 & 5.80 & 5.48 & 5.28 & 4.56 & $4.37^{*}$ & + & + & - \\
\hline MON277 & 3 & 6.37 & 6.20 & 6.05 & 5.78 & 5.18 & $4.76^{*}$ & + & - & - \\
\hline MON281 & 1 & 6.24 & 5.88 & 5.41 & 5.19 & $4.50^{*}$ & 4.35 & + & + & - \\
\hline MON287 & 2 & 6.33 & 6.11 & 5.65 & 5.34 & $4.65^{*}$ & 4.42 & + & + & - \\
\hline MON288 & 1 & 6.26 & 5.89 & 5.37 & 5.21 & $4.59^{*}$ & 4.44 & + & + & - \\
\hline MON298 & 3 & 6.39 & 6.26 & 6.21 & 6.12 & 5.33 & $4.29^{*}$ & + & - & - \\
\hline
\end{tabular}

After $24 \mathrm{~h}$ of incubation, the $\mathrm{pH}$ of milk decreased to: $\mathrm{pH}<4.65$ (group 1), $\mathrm{pH}=4.65$ (group 2) and $\mathrm{pH}>4.65$ (group 3)

* coagulation

substances and others $(21,58)$. Within our study none of the lactococci showed any activity against the Gram-negative indicator bacteria (Enterobacter spp., Pseudomonas spp. and Serratia spp.). According to Rodríguez et al. (59), $\mathrm{LAB}$ bacteriocins are generally inactive against Gram- -negative bacteria due to their resistance conferred by the outer membrane. The test strains were also less effective in reducing the growth of two Listeria spp. strains (DSM 15675 and DSM 20649), which may be related to the production of organic acids or hydrogen peroxide. However, 
seven of the 40 Lactococcus strains were able to inhibit the growth of Staphylococcus aureus strains and isolates (DSM 1104, DSM 20231 and SA17) (Table 3). Nevertheless, char- acterising these strains for antibacterial compounds using the agar well diffusion assay, no inhibition zone could be observed. Similar results were reported by Ammor et al.

Table 3. Antimicrobial activity of 40 tested Lactococcus lactis strains

\begin{tabular}{|c|c|c|c|c|c|c|c|c|c|c|c|c|c|c|}
\hline \multirow{2}{*}{$\begin{array}{l}\text { Tested } \\
\text { strain }\end{array}$} & \multirow{2}{*}{ Group } & \multicolumn{3}{|c|}{$\begin{array}{c}\text { Staphylococcus } \\
\text { aureus }\end{array}$} & \multicolumn{2}{|c|}{$\begin{array}{l}\text { Listeria } \\
\text { spp. }\end{array}$} & \multicolumn{2}{|c|}{$\begin{array}{l}\text { Escherichia } \\
\text { spp. }\end{array}$} & \multicolumn{2}{|c|}{$\begin{array}{c}\text { Enterobacter } \\
\text { spp. }\end{array}$} & \multicolumn{2}{|c|}{$\begin{array}{l}\text { Serratia } \\
\text { spp. }\end{array}$} & \multicolumn{2}{|c|}{$\begin{array}{l}\text { Pseudomonas } \\
\text { spp. }\end{array}$} \\
\hline & & $\begin{array}{l}\text { DSM } \\
1104\end{array}$ & $\begin{array}{l}\text { DSM } \\
20231\end{array}$ & SA17 & $\begin{array}{l}\text { DSM } \\
15675\end{array}$ & $\begin{array}{l}\text { DSM } \\
20649\end{array}$ & EC7 & EC9 & $\begin{array}{r}\text { DSM } \\
30053\end{array}$ & EN3 & $\begin{array}{l}\text { DSM } \\
4487\end{array}$ & EN1 & $\begin{array}{l}\text { DSM } \\
1117\end{array}$ & $\begin{array}{l}\text { DSM } \\
50090\end{array}$ \\
\hline MON101 & 1 & - & - & - & $(+)$ & $(+)$ & - & - & - & - & - & - & - & - \\
\hline MON102 & 1 & - & - & - & $(+)$ & $(+)$ & - & - & - & - & - & - & - & - \\
\hline MON104 & 1 & - & - & - & $(+)$ & $(+)$ & - & - & - & - & - & - & - & - \\
\hline MON108 & 1 & - & - & - & $(+)$ & $(+)$ & - & - & - & - & - & - & - & - \\
\hline MON111 & 1 & - & - & - & $(+)$ & $(+)$ & - & - & - & - & - & - & - & - \\
\hline MON112 & 1 & - & - & - & $(+)$ & $(+)$ & - & - & - & - & - & - & - & - \\
\hline MON125 & 3 & - & - & - & $(+)$ & $(+)$ & - & - & - & - & - & - & - & - \\
\hline MON126 & 1 & - & - & - & $(+)$ & $(+)$ & - & - & - & - & - & - & - & - \\
\hline MON127 & 3 & - & - & - & $(+)$ & $(+)$ & - & - & - & - & - & - & - & - \\
\hline MON128 & 3 & - & + & - & $(+)$ & $(+)$ & - & - & - & - & - & - & - & - \\
\hline MON129 & 1 & - & - & - & $(+)$ & $(+)$ & - & - & - & - & - & - & - & - \\
\hline MON131 & 3 & - & - & - & $(+)$ & $(+)$ & - & - & - & - & - & - & - & - \\
\hline MON132 & 1 & - & - & - & $(+)$ & $(+)$ & - & - & - & - & - & - & - & - \\
\hline MON133 & 3 & - & - & - & $(+)$ & $(+)$ & - & - & - & - & - & - & - & - \\
\hline MON136 & 1 & - & - & - & $(+)$ & $(+)$ & - & - & - & - & - & - & - & - \\
\hline MON147 & 1 & - & - & - & $(+)$ & $(+)$ & - & - & - & - & - & - & - & - \\
\hline MON150 & 3 & - & - & - & $(+)$ & $(+)$ & - & - & - & - & - & - & - & - \\
\hline MON152 & 1 & - & - & $(+)$ & $(+)$ & $(+)$ & - & - & - & - & - & - & - & - \\
\hline MON153 & 1 & - & - & - & $(+)$ & $(+)$ & - & - & - & - & - & - & - & - \\
\hline MON154 & 1 & - & - & - & $(+)$ & $(+)$ & - & - & - & - & - & - & - & - \\
\hline MON164 & 1 & - & - & + & $(+)$ & $(+)$ & - & - & - & - & - & - & - & - \\
\hline MON166 & 1 & $(+)$ & $(+)$ & + & $(+)$ & $(+)$ & - & - & - & - & - & - & - & - \\
\hline MON167 & 1 & $(+)$ & $(+)$ & + & $(+)$ & $(+)$ & - & - & - & - & - & - & - & - \\
\hline MON168 & 3 & $(+)$ & $(+)$ & + & $(+)$ & $(+)$ & - & - & - & - & - & - & - & - \\
\hline MON170 & 1 & - & $(+)$ & + & $(+)$ & $(+)$ & - & - & - & - & - & - & - & - \\
\hline MON171 & 3 & + & $(+)$ & + & $(+)$ & $(+)$ & - & - & - & - & - & - & - & - \\
\hline MON172 & 3 & + & $(+)$ & + & $(+)$ & $(+)$ & - & - & - & - & - & - & - & - \\
\hline MON174 & 3 & $(+)$ & + & + & $(+)$ & $(+)$ & - & - & - & - & - & - & - & - \\
\hline MON185 & 1 & - & - & + & $(+)$ & $(+)$ & - & - & - & - & - & - & - & - \\
\hline MON207 & 3 & $(+)$ & + & + & $(+)$ & $(+)$ & - & - & - & - & - & - & - & - \\
\hline MON208 & 1 & - & $(+)$ & + & $(+)$ & $(+)$ & - & - & - & - & - & - & - & - \\
\hline MON257 & 3 & - & - & - & $(+)$ & $(+)$ & - & - & - & - & - & - & - & - \\
\hline MON259 & 3 & - & - & $(+)$ & $(+)$ & $(+)$ & - & - & - & - & - & - & - & - \\
\hline MON260 & 3 & $(+)$ & - & + & $(+)$ & $(+)$ & - & - & - & - & - & - & - & - \\
\hline MON265 & 1 & - & - & - & $(+)$ & $(+)$ & - & - & - & - & - & - & - & - \\
\hline MON277 & 3 & $(+)$ & - & + & $(+)$ & $(+)$ & - & - & - & - & - & - & - & - \\
\hline MON281 & 1 & - & - & - & $(+)$ & $(+)$ & - & - & - & - & - & - & - & - \\
\hline MON287 & 2 & - & - & + & $(+)$ & $(+)$ & - & - & - & - & - & - & - & - \\
\hline MON288 & 1 & - & - & + & $(+)$ & $(+)$ & - & - & - & - & - & - & - & - \\
\hline MON298 & 3 & - & - & + & $(+)$ & $(+)$ & - & - & - & - & - & - & - & - \\
\hline
\end{tabular}

After $24 \mathrm{~h}$ of incubation, the $\mathrm{pH}$ of milk decreased to: $\mathrm{pH}<4.65$ (group 1), $\mathrm{pH}=4.65$ (group 2) and $\mathrm{pH}>4.65$ (group 3); DSM=Deutsche Sammlung von Mikroorganismen (German Collection of Microorganisms); SA17, EC7, EC9, EN3 and EN1=isolates from Montenegrin dairy products; $-=$ no inhibition, i.e. growth like the control, $(+)=$ weak inhibition, i.e. growth between that of the control and no growth, $+=$ total inhibition, i.e. no growth 
(60), as they could only detect antimicrobial activity on agar but not in the cell-free supernatant fluids. These authors had several hypotheses for this phenomenon such as the adsorption of bacteriocin-like substances by filters, their attachment to the cell wall or the inability of the strains to produce inhibitors in liquid cultures (60).

Table 4. Safety evaluation of 40 tested Lactococcus lactis strains

\begin{tabular}{|c|c|c|c|c|c|c|c|c|c|c|c|c|c|}
\hline \multirow{3}{*}{$\begin{array}{l}\text { Tested } \\
\text { strain }\end{array}$} & \multirow{3}{*}{ Group } & \multirow{2}{*}{\multicolumn{3}{|c|}{ Biogenic amine gene }} & \multicolumn{9}{|c|}{ Antimicrobial susceptibility } \\
\hline & & & & & \multicolumn{9}{|c|}{$\mathrm{MIC} /(\mu \mathrm{g} / \mathrm{mL})$} \\
\hline & & HDC & TDC & ODC & AMP & VAN & GEN & KAN & STR & ERY & CLI & TET & $\mathrm{CHL}$ \\
\hline MON101 & 1 & - & - & - & 0.5 & 0.5 & 4 & 16 & $128^{*}$ & 0.25 & 0.5 & 0.5 & 4 \\
\hline MON102 & 1 & - & - & - & 0.5 & 0.5 & 8 & 16 & $128^{*}$ & 0.25 & 0.5 & 0.5 & 4 \\
\hline MON104 & 1 & - & - & - & 0.5 & 0.5 & 4 & 16 & $64^{*}$ & 0.25 & 0.25 & 0.5 & 4 \\
\hline MON108 & 1 & - & - & - & 0.5 & 0.5 & 4 & 16 & $64^{*}$ & 0.25 & 0.5 & 0.5 & 4 \\
\hline MON111 & 1 & - & - & - & 0.5 & 0.5 & 8 & 16 & $128^{*}$ & 0.25 & 0.25 & 0.5 & 4 \\
\hline MON112 & 1 & - & - & - & 0.5 & 0.5 & 4 & 16 & $64^{*}$ & 0.25 & 0.25 & 0.5 & 4 \\
\hline MON125 & 3 & - & - & - & 0.5 & 0.5 & 2 & 8 & 32 & 0.25 & 0.12 & 0.25 & 4 \\
\hline MON126 & 1 & - & - & - & 0.5 & 0.5 & 4 & 8 & 32 & 0.25 & 0.25 & 0.25 & 4 \\
\hline MON127 & 3 & - & - & - & 0.5 & 0.5 & 4 & 8 & 32 & 0.25 & 0.25 & 0.25 & 4 \\
\hline MON128 & 3 & - & - & - & 0.5 & 0.5 & 4 & 8 & 32 & 0.25 & 0.25 & 0.25 & 4 \\
\hline MON129 & 1 & - & - & - & 0.5 & 0.5 & 2 & 8 & $256^{*}$ & 0.25 & 0.12 & 0.25 & 4 \\
\hline MON131 & 3 & - & - & - & 0.5 & 0.5 & 4 & 8 & 32 & 0.25 & 0.25 & 0.25 & 4 \\
\hline MON132 & 1 & - & - & - & 0.5 & 0.5 & 2 & 8 & 32 & 0.25 & 0.12 & 0.25 & 4 \\
\hline MON133 & 3 & - & - & - & 0.5 & 0.5 & 4 & 16 & 32 & 0.25 & 0.12 & 0.25 & 4 \\
\hline MON136 & 1 & - & - & - & 0.25 & 0.5 & 2 & 8 & 16 & 0.25 & 0.06 & 0.5 & 8 \\
\hline MON147 & 1 & - & - & - & 0.25 & 0.5 & 2 & 4 & 16 & 0.25 & 0.12 & 0.25 & 4 \\
\hline MON150 & 3 & - & - & - & 0.25 & 0.5 & 1 & 4 & 32 & 0.25 & 0.06 & 0.5 & 2 \\
\hline MON152 & 1 & - & - & - & 0.5 & 0.5 & 2 & 4 & 32 & 0.25 & 0.12 & 0.5 & 4 \\
\hline MON153 & 1 & - & - & - & 0.25 & 0.5 & 2 & 16 & 16 & 0.25 & 0.12 & 0.5 & 4 \\
\hline MON154 & 1 & - & - & - & 0.25 & 0.5 & 2 & 8 & 32 & 0.25 & 0.12 & 0.5 & 4 \\
\hline MON164 & 1 & - & - & + & 0.5 & 0.5 & 2 & 8 & 32 & 0.25 & 0.06 & 0.5 & 4 \\
\hline MON166 & 1 & - & - & - & 0.5 & 0.5 & 4 & 16 & 16 & 0.25 & 0.06 & 0.5 & 8 \\
\hline MON167 & 1 & - & - & - & 0.25 & 0.5 & 4 & 16 & 32 & 0.25 & 0.25 & 0.5 & 8 \\
\hline MON168 & 3 & - & - & - & 0.5 & 0.5 & 2 & 8 & 32 & 0.25 & 0.12 & 0.5 & 4 \\
\hline MON170 & 1 & - & - & - & 0.5 & 0.5 & 2 & 8 & 32 & 0.25 & 0.06 & 0.5 & 8 \\
\hline MON171 & 3 & - & - & - & 0.5 & 0.5 & 4 & 16 & $64^{*}$ & $2^{*}$ & 0.25 & 0.5 & 8 \\
\hline MON172 & 3 & - & - & - & 0.5 & 0.5 & 2 & 8 & 32 & 0.25 & 0.06 & 0.5 & 8 \\
\hline MON174 & 3 & - & - & - & 0.5 & 1.0 & 1 & 4 & $128^{*}$ & $2^{*}$ & 0.12 & 0.5 & 4 \\
\hline MON185 & 1 & - & - & - & 0.25 & 0.5 & 2 & 4 & 16 & 0.25 & 0.06 & 0.25 & 8 \\
\hline MON207 & 3 & - & - & - & 0.5 & 0.5 & 2 & 8 & 32 & 0.25 & 0.06 & 0.5 & 8 \\
\hline MON208 & 1 & - & - & - & 0.5 & 0.5 & 2 & 4 & 16 & 0.25 & 0.06 & 0.5 & 8 \\
\hline MON257 & 3 & - & - & - & 0.5 & 0.5 & 2 & 4 & 32 & 0.25 & 0.06 & 0.25 & 8 \\
\hline MON259 & 3 & - & - & - & 0.25 & 0.5 & 2 & 8 & 32 & 0.25 & 0.06 & 0.5 & 4 \\
\hline MON260 & 3 & - & - & - & 0.5 & 0.5 & 4 & 16 & $64^{*}$ & 0.25 & 0.12 & 0.5 & 4 \\
\hline MON265 & 1 & - & - & - & 0.25 & 0.5 & 4 & 16 & 16 & 0.25 & 0.06 & 0.5 & 4 \\
\hline MON277 & 3 & - & - & - & 0.5 & 0.5 & 4 & 16 & $64^{*}$ & 0.25 & 0.12 & 0.5 & 4 \\
\hline MON281 & 1 & - & - & - & 0.25 & 0.5 & 4 & 8 & 32 & 0.25 & 0.12 & 0.5 & 4 \\
\hline MON287 & 2 & - & - & - & 0.5 & 0.5 & 4 & 16 & $64^{*}$ & 0.25 & 0.06 & 1 & 8 \\
\hline MON288 & 1 & - & - & - & 0.25 & 0.5 & 4 & 16 & $64^{*}$ & 0.25 & 0.06 & 0.5 & 4 \\
\hline MON298 & 3 & - & - & + & 0.25 & 0.5 & 2 & 8 & $64^{*}$ & 0.25 & 0.12 & 0.5 & 4 \\
\hline
\end{tabular}

After $24 \mathrm{~h}$ of incubation, the $\mathrm{pH}$ of milk decreased to: $\mathrm{pH}<4.65$ (group 1), $\mathrm{pH}=4.65$ (group 2) and $\mathrm{pH}>4.65$ (group 3); $\mathrm{MIC}=$ minimum inhibitory concentration; HDC=histidine decarboxylase, TDC=tyrosine decarboxylase, $\mathrm{ODC}=$ ornithine decarboxylase; $\mathrm{AMP}=$ ampicillin, VAN=vancomycin, GEN=gentamicin, KAN=kanamycin, STR=streptomycin, ERY=erythromycin, CLI=clindamycin, TET=tetracycline, $\mathrm{CHL}=$ chloramphenicol; ${ }^{*}$ resistant according to EFSA (61) 
The biogenic amines most commonly found in fermented dairy products are histamine and tyramine, but putrescine is also frequently detected (62). Thus, PCR was used to amplify fragments of genes coding for HDC, TDC and ODC. While no amplicons for HDC and TDC could be observed, two strains were positive for ODC (Table 4). The PCR products of these strains were subjected to sequencing for confirmation. The obtained sequences verified the result as they corresponded to fragments of the ODC gene, detected in Oenoccocus oeni strains (GenBank accession no. FR751075.1-FR751079.1) (27). According to Ladero et al. (63), L. lactis is one of the main putrescine producers in cheese. However, only L. lactis strains producing putrescine by the agmatine deiminase (AgDI) pathway and not by the ornithine decarboxylase (ODC) pathway have been described (63). Although some L. lactis strains have been reported as potential histamine or tyramine formers (64), none of the relevant genes was found within our study. Similarly, Priyadarshani and Rakshit (64) could not observe any histamine and tyramine formation in their tested L. lactis strains.

Using the cut-off values of EFSA (61) to distinguish resistant from susceptible strains, all lactococci were susceptible to the tested antibiotics except for streptomycin and erythromycin (Table 4). While only two strains slightly exceeded the cut-off value of erythromycin, approximately one third of the investigated strains can be classified as resistant to streptomycin according to EFSA (61). However, the typical MIC distribution for wild type organisms covers three to five adjacent 2 -fold dilution steps surrounding the modal MIC (65). This applies to the streptomycin MIC distribution obtained within our study (Table 4). As a wild type organism is defined as a strain which does not harbour acquired resistance to the examined antibiotic (66), the higher streptomycin MICs might be natural in L. lactis. High streptomycin MIC values for lactococci were also observed by Fernández et al. (8), Toomey et al. (67) and Rodríguez-Alonso et al. (68). Nevertheless, the possibility of the presence of antibiotic resistance genes should not be ignored and needs further investigations. For instance, a decreased susceptibility to erythromycin due to a multidrug transporter encoded by the gene $m d t$ (A) was shown in L. lactis (69). Otherwise the erythromycin-resistance gene $\operatorname{erm}(\mathrm{B})$ could likewise be responsible for the higher MIC values of the two Lactococcus strains, as this gene was also found in intermediate-level resistant $(2-16 \mu \mathrm{g} / \mathrm{mL})$ L. garviae isolates (70).

\section{Conclusions}

Our study suggests that 11 (27.5\%) of the 40 tested Lactococcus lactis ssp. lactis strains have a potential to be used as starter cultures for the production of traditional Montenegrin cheese. Of course, further studies such as an investigation of antimicrobial resistance determinants have to be done to assure the innocuousness of these strains. For a successful application of these well characterised lactococci in dairy industry, it is also necessary to determine the biochemical reactions that take place during fermentation and ripening of the product due to the activity of these bacteria. Thus, after inoculating milk with these strains, changes of microbial, physical, chemical and sensory characteristics during fermentation and ripening of cheese as well as the final product should be monitored.

\section{Acknowledgements}

The authors thank the Science and Technology Cooperation (WTZ) of the Austrian agency for international mobility and cooperation in education, science and research (OeAD) for the given support (bilateral project: 'Identity and basic characterization of potential lactic acid bacteria starter cultures isolated from traditionally fermented milk in Montenegro' - ME 02/2011). The study was partly funded by the Ministry of Science of Montenegro (national project: 'Isolation and characterization of autochthonous lactic acid bacteria to be used for the production of specific cheeses in Montenegro' - No 49/2008). We are also thankful to Dr. Ljubiša Topisirović for his help in the preparation and application of the national project.

\section{References}

1. Abd El Gawad IA, Abd El Fatah AM, Al Rubayyi KA. Identification and characterization of dominant lactic acid bacteria isolated from traditional Rayeb milk in Egypt. J Am Sci. 2010; 6:728-35.

2. Jokovic N, Nikolic M, Begovic J, Jovcic B, Savic D, Topisirovic $\mathrm{Lj}$. A survey of the lactic acid bacteria isolated from Serbian artisanal dairy product kajmak. Int J Food Microbiol. 2008;127:305-11. http://dx.doi.org/10.1016/j.ijfoodmicro.2008.07.026

3. Terzic-Vidojevic A, Vukasinovic M, Veljovic K, Ostojic M, Topisirovic L. Characterization of microflora in homemade semi-hard white Zlatar cheese. Int J Food Microbiol. 2007;114:3642. http://dx.doi.org/10.1016/j.ijfoodmicro.2006.10.038

4. Topisirovic L, Kojic M, Fira D, Golic N, Strahinic I, Lozo J. Potential of lactic acid bacteria isolated from specific natural niches in food production and preservation. Int J Food Microbiol. 2006;112:230-5. http://dx.doi.org/10.1016/j.ijfoodmicro.2006.04.009

5. Beresford TP, Fitzsimons NA, Brennan NL, Cogan TM. Recent advances in cheese microbiology. Int Dairy J. 2001;11:259-74. http://dx.doi.org/10.1016/S0958-6946(01)00056-5

6. Martinović A, Radulović Z, Wind A, Janzen T, Obradović D. Isolation and characterization of bacterial flora from farmhouse fermented milk products of Serbia and Montenegro. Acta Vet (Beogr). 2005;55:307-18.

7. Tormo H, Ali Haimoud Lekhal D, Roques C. Phenotypic and genotypic characterization of lactic acid bacteria isolated from raw goat milk and effect of farming practices on the dominant species of lactic acid bacteria. Int J Food Microbiol. 2015;210:9-15.

http://dx.doi.org/10.1016/j.ijfoodmicro.2015.02.002

8. Fernández E, Alegría Á, Delgado S, Martín MC, Mayo B. Comparative phenotypic and molecular genetic profiling of wild Lactococcus lactis subsp. lactis strains of the L. lactis subsp. lactis and L. lactis subsp. cremoris genotypes, isolated from starter-free cheeses made of raw milk. Appl Environ Microbiol. 2011;77:5324-35. http://dx.doi.org/10.1128/AEM.02991-10

9. Torriani S, Felis GE, Fracchetti F. Selection criteria and tools for malolactic starters development: an update. Ann Microbiol. 2011;61:33-9.

http://dx.doi.org/10.1007/s13213-010-0072-x

10. Domig KJ, Kiss H, Petricevic L, Viernstein H, Unger F, Kneifel W. Strategies for the evaluation and selection of potential vaginal probiotics from human sources: an exemplary study. 
Benef Microbes. 2014;5:263-72.

http://dx.doi.org/10.3920/BM2013.0069

11. Parente E, Cogan TM. Starter cultures: general aspects. In: Fox PF, McSweeney PLH, Cogan TM, Guinee TP, editors. Cheese: chemistry, physics and microbiology, vol. 1. Amsterdam, The Netherlands: Elsevier Ltd.; 2004. pp. 123-47.

http://dx.doi.org/10.1016/S1874-558X(04)80065-4

12. Holzapfel WH, Geisen R, Schillinger U. Biological preservation of foods with reference to protective cultures, bacteriocins and food-grade enzymes. Int J Food Microbiol. 1995;24: 343-62.

http://dx.doi.org/10.1016/0168-1605(94)00036-6

13. Kastner S, Perreten V, Bleuler H, Hugenschmidt G, Lacroix C, Meile L. Antibiotic susceptibility patterns and resistance genes of starter cultures and probiotic bacteria used in food. Syst Appl Microbiol. 2006;29:145-55. http://dx.doi.org/10.1016/j.syapm.2005.07.009

14. Terzaghi BE, Sandine WE. Improved medium for lactic streptococci and their bacteriophages. Appl Microbiol. 1975;29: 807-13.

15. de Man JC, Rogosa M, Sharpe ME. A medium for the cultivation of lactobacilli. J Appl Bacteriol. 1960;23:130-5. http://dx.doi.org/10.1111/j.1365-2672.1960.tb00188.x

16. Nomura M, Kobayashi M, Okamoto T. Rapid PCR-based method which can determine both phenotype and genotype of Lactococcus lactis subspecies. Appl Environ Microbiol. 2002;68: 2209-13. http://dx.doi.org/10.1128/AEM.68.5.2209-2213.2002

17. Huey B, Hall J. Hypervariable DNA fingerprinting in Escherichia coli: minisatellite probe from bacteriophage M13. J Bacteriol. 1989;171:2528-32.

http://dx.doi.org/10.1128/jb.171.5.2528-2532.1989

18. Akopyanz N, Bukanov NO, Westblom TU, Kresovich S, Berg DE. DNA diversity among clinical isolates of Helicobacter pylori detected by PCR based RAPD fingerprinting. Nucl Acids Res. 1992;20:5137-42. http://dx.doi.org/10.1093/nar/20.19.5137

19. Winn WC, Allen SD, Janda WM, Koneman EW, Procop GW, Schreckenberger PC, Woods G. Koneman's color atlas and textbook of diagnostic microbiology. Philadelphia, PA, USA: Lippincott Williams \& Wilkins; 2006.

20. ONPG discs - technical data. Mumbai, India: HiMedia Laboratories Pvt. Ltd.; 2011. Available from: http://www.himedialabs.com/TD/DD008.pdf.

21. Yang E, Fan L, Jiang Y, Doucette C, Fillmore S. Antimicrobial activity of bacteriocin-producing lactic acid bacteria isolated from cheeses and yogurts. AMB Express. 2012;2:48. http://dx.doi.org/10.1186/2191-0855-2-48

22. Semedo-Lemsaddek T, Tenreiro R, Lopes Alves P, Barreto Crespo MT. Enterococcus. In: Liu D, editor. Molecular detection of foodborne pathogens. Boca Raton, FL, USA: CRC Press; 2010. pp. 157-79.

23. Le Jeune C, Lonvaud-Funel A, ten Brink B, Hofstra $H$, van der Vossen JMBM. Development of a detection system for histidine decarboxylating lactic acid bacteria based on DNA probes, PCR and activity test. J Appl Bacteriol. 1995;78:31626.

http://dx.doi.org/10.1111/j.1365-2672.1995.tb05032.x

24. Lucas P, Lonvaud-Funel A. Purification and partial gene sequence of the tyrosine decarboxylase of Lactobacillus brevis IOEB 9809. FEMS Microbiol Lett. 2002;211:85-9. http://dx.doi.org/10.1111/j.1574-6968.2002.tb11207.x

25. Lucas P, Landete J, Coton M, Coton E, Lonvaud-Funel A. The tyrosine decarboxylase operon of Lactobacillus brevis IOEB 9809: characterization and conservation in tyramine-producing bacteria. FEMS Microbiol Lett. 2003;229:65-71. http://dx.doi.org/10.1016/S0378-1097(03)00787-0
26. Nannelli F, Claisse O, Gindreau E, De Revel G, Lonvaud-Funel A, Lucas PM. Determination of lactic acid bacteria producing biogenic amines in wine by quantitative PCR methods. Lett Appl Microbiol. 2008;47:594-9. http://dx.doi.org/10.1111/j.1472-765X.2008.02472.x

27. Basic Local Alignment Search Tool (BLAST). Bethesda, MD, USA: National Center for Biotechnology Information, US National Library of Medicine. Available from: https://blast. ncbi.nlm.nih.gov/Blast.cgi.

28. ISO 10932/IDF 223:2010. Milk and milk products - Determination of the minimal inhibitory concentration (MIC) of antibiotics applicable to bifidobacteria and non-enterococcal lactic acid bacteria (LAB). Geneva, Switzerland: International Organization for Standardization (ISO); 2010.

29. Kim W. The genus Lactococcus. In: Holzapfel WH, Wood BJB, editors. Lactic acid bacteria: biodiversity and taxonomy. Chichester, UK: John Wiley \& Sons; 2014. pp. 429-43. http://dx.doi.org/10.1002/9781118655252.ch26

30. Axelsson LT. Lactic acid bacteria: classification and physiology. In: Salminen S, von Wright A, editors. Lactic acid bacteria. New York, NY, USA: Marcel Dekker; 1993. pp. 1-63.

31. Smit G, van Hylckama VJET, Smit BA, Ayad EHE, Engels WJM. Fermentative formation of flavour compounds by lactic acid bacteria. Aust J Dairy Technol. 2002;57:61-8.

32. Facklam R, Elliott JA. Identification, classification, and clinical relevance of catalase-negative, gram-positive cocci, excluding the streptococci and enterococci. Clin Microbiol Rev. 1995;8:479-95.

33. Corroler D, Mangin I, Desmasures N, Gueguen M. An ecological study of lactococci isolated from raw milk in the Camembert cheese registered designation of origin area. Appl Environ Microbiol. 1998;64:4729-35.

34. Samaržija D, Antunac N, Lukač-Havranek J. Taxonomy, physiology and growth of Lactococcus lactis: a review. Mljekarstvo. 2001;51:35-48.

35. Wouters JA, Kamphuis HH, Hugenholtz J, Kuipers OP, de Vos WM, Abee T. Changes in glycolytic activity of Lactococcus lactis induced by low temperature. Appl Environ Microbiol. 2000;66:3686-91. http://dx.doi.org/10.1128/AEM.66.9.3686-3691.2000

36. Garnier M, Matamoros S, Chevret D, Pilet MF, Lero F, Tresse O. Adaptation to cold and proteomic responses of the psychrotrophic biopreservative Lactococcus piscium strain CNCM I-4031. Appl Environ Microbiol. 2010;76:8011-8. http://dx.doi.org/10.1128/AEM.01331-10

37. Leducq JB, Charron G, Samani P, Dubé AK, Sylvester K, James B, et al. Local climatic adaptation in a widespread microorganism. Proc Roy Soc B. 2014;281:20132472. http://dx.doi.org/10.1098/rspb.2013.2472

38. Radulović Z, Martinović A, Radin D, Obradović D. Lactic acid bacteria strains isolated from Sjenica cheese. Biotechnol Anim Husb. 2004;20:49-54 (in Serbian). http://dx.doi.org/10.2298/BAH0404049R

39. Dozet N, Adžić N, Stanišić M, Živić N. Autochthonous dairy products. Podgorica: Montenegro: Poljoprivredni institut; 1996 (in Serbian).

40. Bojanić-Rašović M, Mirecki S, Nikolić N, Vučinić S, Ivanović I, Rašović R. Microbiological and chemical quality of autochthonous cheese in Montenegro. Prehrambena industrija. 2010; 21:127-33 (in Serbian).

41. Stanely G. Cheeses. In: Wood BJB, editor. Microbiology of fermented foods. London, UK: Blackie Academic \& Professional; 1998. pp. 263-307. http://dx.doi.org/10.1007/978-1-4613-0309-1_10

42. Kojić M, Lozo J, Begović J, Jovčić B, Topisirović LJ. Characterization of lactococci isolated from homemade kefir. Arch 
Biol Sci. 2007;59:13-22.

http://dx.doi.org/10.2298/ABS0701013K

43. Veljovic K, Terzic-Vidojevic A, Vukasinovic M, Strahinic I, Begovic J, Lozo J, et al. Preliminary characterization of lactic acid bacteria isolated from Zlatar cheese. J Appl Microbiol. 2007;103:2142-52.

http://dx.doi.org/10.1111/j.1365-2672.2007.03450.x

44. Cachon R, Jeanson S, Aldarf M, Divies C. Characterization of lactic acid starters based on acidification and reduction activities. Lait. 2002;82:281-8. http://dx.doi.org/10.1051/lait:2002010

45. Martinović A. Classification of lactic acid bacteria isolated from autochthonous fermented dairy products [Master Thesis]. Belgrade, Serbia: University of Belgrade; 2003 (in Serbi“can).

46. Rodríguez A, Martínez B, Suárez JE. Dairy starter cultures. In: Hui YH, Özgül Evranuz E, editors. Handbook of animalbased fermented food and beverage technology. Boca Raton, FL, USA: CRC Press; 2012. pp. 31-48. http://dx.doi.org/10.1021/b12084-4

47. Lawrence CR, Thomas TD, Terzaghi BE. Reviews of the progress of dairy science: cheese starters. J Dairy Res. 1976;43: 141-93.

http://dx.doi.org/10.1017/S0022029900015703

48. De Vos WM, Gasson MJ. Structure and expression of the Lactococcus lactis gene for phospho- $\beta$-galactosidase (lacG) in Escherichia coli and L. lactis. J Gen Microbiol. 1989;135:183346.

49. Aleksandrzak-Piekarczyk T, Kok J, Renault P, Bardowski J. Alternative lactose catabolic pathway in Lactococcus lactis IL 1403. Appl Environ Microbiol. 2005;71:6060-9. http://dx.doi.org/10.1128/AEM.71.10.6060-6069.2005

50. Visser S. Proteolytic enzymes and their relation to cheese ripening and flavor: an overview. J Dairy Sci. 1993;76:329-50. http://dx.doi.org/10.3168/jds.S0022-0302(93)77354-3

51. Fox PF, McSweeney PLH. Proteolysis in cheese during ripening. Food Rev Int. 1996;12:457-509. http://dx.doi.org/10.1080/87559129609541091

52. St-Gelais D, Roy D, Haché S, Desjardins ML. Growth of nonproteolytic Lactococcus lactis in culture medium supplemented with different casein hydrolyzates. J Dairy Sci. 1993;76:3327-37. http://dx.doi.org/10.3168/jds.S0022-0302(93)77670-5

53. Katz M, Medina R, Gonzales S, Oliver G. Esterolytic and lipolytic activities of lactic acid bacteria isolated from ewe's milk and cheese. J Food Prot. 2002;65:1997-2001. http://dx.doi.org//10.4315/0362-028X-65.12.1997

54. Walstra P, Woulters JTM, Guerts TJ. Dairy science and technology. Boca Raton, FL, USA: CRC Press; 2005. http://dx.doi.org/10.1201/9781420028010.ch3

55. Ouadghiri M, Vancanneyt M, Vandamme P, Naser S, Gevers $\mathrm{D}$, Lefebvre $\mathrm{K}$, et al. Identification of lactic acid bacteria in Moroccan raw milk and traditionally fermented skimmed milk 'lben'. J Appl Microbiol. 2009;106:486-95. http://dx.doi.org/10.1111/j.1365-2672.2008.04016.x

56. Medina RB, Katz MB, González S, Oliver G. Determination of esterolytic and lipolytic activities of lactic acid bacteria. In: Spencer JFT, Ragout de Spencer AL, editors. Methods in molecular biology, vol. 268: Public health microbiology. Totowa, NJ, USA: Humana Press Inc.; 2004 pp. 465-70. http://dx.doi.org/10.1385/1-59259-766-1:465

57. Meyers SA, Cuppett SL, Hutkins RW. Lipase production by lactic acid bacteria and activity on butter oil. Food Microbiol. 1996;13:383-9. http://dx.doi.org/10.1006/fmic.1996.0044

58. Favaro L, Barretto Penna AL, Todorov SD. Bacteriocinogenic LAB from cheeses - application in biopreservation? Trends
Food Sci Technol. 2015;41:37-48.

http://dx.doi.org/10.1016/j.tifs.2014.09.001

59. Rodríguez E, Calzada J, Arqués JL, Rodríguez JM, Nuñez M, Medina M. Antimicrobial activity of pediocin-producing Lactococcus lactis on Listeria monocytogenes, Staphylococcus aureus and Escherichia coli O157:H7 in cheese. Int Dairy J. 2005;15:51-7. http://dx.doi.org/10.1016/j.idairyj.2004.05.004

60. Ammor S, Tauveron G, Dufour E, Chevallier I. Antibacterial activity of lactic acid bacteria against spoilage and pathogenic bacteria isolated from the same meat small-scale facility: 1-screening and characterization of the antibacterial compounds. Food Control. 2006;17:454-61. http://dx.doi.org/10.1016/j.foodcont.2005.02.006

61. European Food Safety Authority (EFSA). Guidance on the assessment of bacterial susceptibility to antimicrobials of human and veterinary importance. EFSA J. 2012;10:2740. http://dx.doi.org/10.2903/j.efsa.2012.2740

62. Linares DM, del Río B, Ladero V, Redruello B, Cruz Martín M, Fernández M, Alvarez MA. The putrescine biosynthesis pathway in Lactococcus lactis is transcriptionally regulated by carbon catabolic repression, mediated by CcpA. Int J Food Microbiol. 2013;165:43-50. http://dx.doi.org/10.1016/j.ijfoodmicro.2013.04.021

63. Ladero V, Cañedo E, Pérez M, Martín MC, Fernández M, Alvarez MA. Multiplex qPCR for the detection and quantification of putrescine-producing lactic acid bacteria in dairy products. Food Control. 2012;27:307-13. http://dx.doi.org/10.1016/j.foodcont.2012.03.024

64. Priyadarshani WMD, Rakshit SK. Screening selected strains of probiotic lactic acid bacteria for their ability to produce biogenic amines (histamine and tyramine). Int J Food Sci Technol. 2011;46:2062-9. http://dx.doi.org/10.1111/j.1365-2621.2011.02717.x

65. Arendrup MC, Kahlmeter G, Rodriguez-Tudela J, Donnelly JP. Breakpoints for susceptibility testing should not divide wild-type distributions of important target species. Antimicrob Agents Chemother. 2009;53:1628-9. http://dx.doi.org/10.1128/AAC.01624-08

66. Pfaller MA, Castanheira M, Diekema DJ, Messer SA, Jones RN. Wild-type MIC distributions and epidemiologic cutoff values for fluconazole, posaconazole, and voriconazole when testing Cryptococcus neoformans as determined by the CLSI broth microdilution method. Diagn Microbiol Infect Dis. 2011; 71:252-9. http://dx.doi.org/10.1016/j.diagmicrobio.2011.07.007

67. Toomey N, Bolton D, Fanning S. Characterisation and transferability of antibiotic resistance genes from lactic acid bacteria isolated from Irish pork and beef abattoirs. Res Microbiol. 2010;161:127-35. http://dx.doi.org/10.1016/j.resmic.2009.12.010

68. Rodríguez-Alonso P, Fernández-Otero C, Centeno JA, Garabal JI. Antibiotic resistance in lactic acid bacteria and Micrococcaceae/Staphylococcaceae isolates from artisanal raw milk cheeses, and potential implications on cheese making. J Food Sci. 2009;74:M284-93. http://dx.doi.org/10.1111/j.1750-3841.2009.01217.x

69. Perreten V, Schwarz FV, Teuber M, Levy SB. Mdt(A), a new efflux protein conferring multiple antibiotic resistance in Lactococcus lactis and Escherichia coli. Antimicrob Agents Chemother. 2001;45:1109-14. http://dx.doi.org/10.1128/AAC.45.4.1109-1114.2001

70. Kawanishi M, Kojima A, Ishihara K, Esaki H, Kijima M, Takahashi T, et al. Drug resistance and pulsed-field gel electrophoresis patterns of Lactococcus garvieae isolates from cultured Seriola (yellowtail, amberjack and kingfish) in Japan. Lett Appl Microbiol. 2005;40:322-8. http://dx.doi.org/10.1111/j.1472-765X.2005.01690.x 